\title{
Assessing the knowledge, attitude and practice of contraception in rural India: a necessary step in achieving population control
}

\author{
Ashwini Nayak U.*, Ramakrishnan K. G., Venkateswar K. N., Vijayshree M.
}

Department of Obstetrics and Gynecology, M. S. Ramaiah Medical College, Bengaluru, Karnataka, India

Received: 27 June 2017

Accepted: 04 July 2017

\section{*Correspondence:}

Dr. Ashwini Nayak U.,

E-mail: ashwininayaku@gmail.com

Copyright: () the author(s), publisher and licensee Medip Academy. This is an open-access article distributed under the terms of the Creative Commons Attribution Non-Commercial License, which permits unrestricted non-commercial use, distribution, and reproduction in any medium, provided the original work is properly cited.

\begin{abstract}
Background: India's projected population will be 1.53 Billion by the year 2050. Every fifth birth in the world is an Indian, and $50 \%$ percent of the Indian population are of reproductive age. Objective of present work was to study the knowledge, attitude and practice of contraception among rural women.

Methods: 100 rural women in the study were evaluated with the help of a pre-designed and pre-tested questionnaire for the knowledge regarding contraception.

Results: Though all women were aware of at least one contraceptive method, $11 \%$ never used contraception. The most commonly used contraceptive was condom 59\%, followed by $41 \%$ CU-T, $27 \%$ tubectomy, $18 \%$ pills, $10 \%$ injectable and 3\% emergency contraception.

Conclusions: Though knowledge about at least one contraceptive method existed, there is a strong need for motivational strategies to make people accept the methods. Furthermore, there needs to be more educational programs to increase awareness about the existence of various family planning methods.
\end{abstract}

Keywords: Contraception, Contraceptive methods, KAP

\section{INTRODUCTION}

India's projected population will be 1.53 Billion by the year $2050 .{ }^{1}$ Every fifth birth in the world is an Indian, and $50 \%$ percent of the Indian population are of reproductive age. ${ }^{2}$ This kind of population explosion will only result in the depletion of natural resources which is already scarce. Hence adoption of contraception becomes imperative.

Family planning is not mere birth control, but it encompasses the services, policies, information, attitudes, practices, and commodities, including contraceptives, that give women, men, couples, and adolescents the ability to avoid unintended pregnancy and choose whether and/or when to have a child. ${ }^{3}$ WHO has defined Family Planning as a way of thinking and living that is adopted voluntarily upon the basis of knowledge, attitudes and responsible decisions by individuals and couples in order to promote the health and welfare of the family and thus contribute effectively to the social development of a country. ${ }^{4} \mathrm{~A}$ good family planning program thus not only helps in improving the economic condition of the nation as a whole but also in enhancing the health of the women and children at the family level. Hence there is a great need to address this key problem by knowing the level of awareness of the women regarding contraception. The present study was done to study the knowledge, attitude and practice of rural women towards family planning.

\section{METHODS}

This is a community based cross sectional study in the rural field practice area of Ramaiah medical college at Kaiwara village, in the Chintamani taluk of Chickaballapur district of Karnataka, India. The study 
population comprised of married women in the reproductive age group of $18-45$ years.

\section{Inclusion criteria}

Inclusion Criteria consisted of Women who are married and residing in Kaiwara and those who were capable of effectively communicating in their local language.

\section{Exclusion criteria}

Exclusion Criteria was those who declined to participate.

The data was collected by interviewing the woman using a predesigned and pretested proforma in their own local language. Interview was administered to participants after describing to them the aim of the study, obtaining oral consent, and confidentiality was maintained. A thorough rapport was established with the household members before collecting the information, and privacy was maintained with the informants while collecting the information. Information was collected regarding her age, parity, education, socio-economic status, knowledge about various contraceptives and their usage. Reasons for using and not using contraception and the source of information was also collected. After the interview, the participants were told about the contraceptive methods and thanked for their co-operation.

\section{Statistical analysis}

Statistical Analysis of the data was carried out employing SPSS, version 18.0. Descriptive statistics was employed to summarize the quantitative variables. $\mathrm{P}<0.05$ was considered significant.

\section{RESULTS}

The age of the participants ranged from 18 to 43 years with mean age of $24.15 \pm 5.86$ years. The parity ranged from $0-3$ children $(1.15 \pm 0.80)$. All of the respondents belonged to the low socio-economic status.

Table 1: The distribution of respondents regarding knowledge of family planning based on age.

\begin{tabular}{|lll|}
\hline Age & $\begin{array}{l}\text { No knowledge about family } \\
\text { planning }\end{array}$ & $\%$ \\
\hline$\leq 18$ years & 3 & 3 \\
\hline $19-28$ & 19 & 19 \\
\hline $29-38$ & 6 & 6 \\
\hline$\geq 39$ years & 0 & 0 \\
\hline
\end{tabular}

$54 \%$ of the participants were uneducated, $32 \%$ had studied upto high school and $14 \%$ were graduates. $21 \%$ had knowledge about pills, $29 \%$ about CU-T, $15 \%$ knew vasectomy, $34 \%$ about tubectomy, $8 \%$ injectables and $73 \%$ of the women knew about condoms. If condoms were excluded from the list, $3 \%$ of the women from $\leq 18$ years age, $19 \%$ of the women in $19-28$ years and $6 \%$ of the women from 29-38 years age group had no knowledge about other family planning methods (Table $1)$.

All the women had some knowledge about at least one of the contraceptive methods. Overall the percentage of women who have used the contraception at some point of their life- $18 \%$ of the women used pills, $41 \%$ cu-T, $27 \%$ tubectomy, 59\% condoms, $10 \%$ injectable and $3 \%$ emergency contraception (Table 2).

Table 2: The distribution of the usage of the family planning methods.

\begin{tabular}{|l|l|}
\hline Methods of contraception & $\%$ \\
\hline Pills & 18 \\
\hline CU-T & 41 \\
\hline Condoms & 59 \\
\hline Injectable & 10 \\
\hline Emergency contraception & 3 \\
\hline Tubectomy & 27 \\
\hline
\end{tabular}

$11 \%$ of the women $\leq 18$ years, $38 \%$ in the age group 29 38 years and $3 \%$ in the age group $\geq 39$ years and in the age group 18-28 years almost all women have used some or the other contraceptive method at least once. Majority of the women in the age group $\leq 18$ years and age group $19-28$ years used condoms $(7 \% ; 40 \%)$ while the women in the age group 29-38 years used permanent methods such as tubectomy $(18 \%)$.

Out of the 14 graduates, $21.42 \%(\mathrm{n}=3)$ used pills, $50 \%$ $(\mathrm{n}=7)$ CU-T, 64.2\% $(\mathrm{n}=9)$ tubectomy, 57.14\% $(\mathrm{n}=8)$ condoms, $14.28 \%(\mathrm{n}=2)$ injectables and $7.14 \% \quad(\mathrm{n}=1)$ emergency contraception. Among the 32 of the women who had completed the high school education, $21.87 \%$ $(n=7)$ had taken pills, 46.87\% (n=15) CU-T, 34.37\% $(n=11)$ tubectomy, 50\% $(n=16)$ condoms, 6.25\% $(n=2)$ injectable contraceptive. Out of 54 illiterate women, $14.8 \%$ used pills $(\mathrm{n}=8), 35.18 \%$ used CU-T $(\mathrm{n}=19)$, $16.6 \%$ underwent tubectomy $(n=9), 64.81 \%$ used condoms $(n=35), 11.11 \%$ used injectables $(n=6)$ and $1.85 \%$ used emergency contraception $(n=1)$.

All the graduates had used some or the other contraception at least once. 3 out of 32 women $(9.37 \%)$ who have studied upto high school had never used contraception. 8 out of $54(14.8 \%)$ illiterates had not used contraception. Most of the respondents (32\%) were using permanent sterilization method as they had completed families and $41 \%$ used it for spacing.

$44 \%$ felt that they did not have adequate knowledge about the various methods, $14 \%$ of the women faced partner opposition and hence had no choice in selection of contraceptive method. $27 \%$ had gained the information about family planning methods from newspapers, $56 \%$ from the television media, $25 \%$ from radio, $20 \%$ from elders, $44 \%$ from friends, $32 \%$-doctors and $22 \%$ from posters. 


\section{DISCUSSION}

Almost all the women had knowledge about atleast one contraceptive method. This is similar to the study by Tizta et al in which there was high level of knowledge on at least one form of contraception among the participants $(96 \%) .{ }^{5}$ Another study by Rao PD et al conducted in 2009 revealed that among the 252 Racha Koya women, $81 \%$ had a high level of knowledge on different contraceptive methods. ${ }^{6}$ But coming to utilization of these methods, it was found that $11 \%$ had not used contraception. Studies by Omo-Aghoja $\mathrm{LO}$ et al and Becker $\mathrm{S}$ have already described similar findings, i.e. high awareness but low utilization of contraceptives, making this situation a serious challenge in developing countries. ${ }^{7,8}$

In present study emergency contraception (3\%) was the least used contraceptive methods which is similar to the study by Tizta et al. ${ }^{5}$ This fact emphasizes that there need to be effective strategies to disseminate information regarding various methods of contraception. $9.37 \%$ of the women who have studied upto high school had not taken any contraception compared to study Gaikwad $\mathrm{S}$ et al where in from the group of studied women $38.23 \%$ did not use any contraceptive methods. ${ }^{9}$ In the present study, the most common contraceptive used was condom 59\% which is comparable to the study by Pegu B et al in which most of them were using condom (38.2\%) followed by Oral Contraceptive Pills (OCPs) (27.6\%), intra uterine contraceptive device $(15.8 \%){ }^{10}$

In the present study, $11 \%$ had not used any contraceptive method which is comparable to the study by Young et al in which it was $8 \% .^{11}$ This is in contrast to the study by Sherpa SZ et al in which $38.23 \%$ whereas $44.6 \%$ in Prachi $\mathrm{R}$ et al study and $55 \%$ in study conducted by Srivastava et al had never used contraceptive methods. ${ }^{12-}$ 14 In the present study, 27\% had knowledge about contraception from newspapers, $56 \%$ from the television media, 25\% from radio, 20\% from elders, $44 \%$ from friends, $32 \%$ from doctors and $22 \%$ from posters. This is similar to the study by Ghike $\mathrm{S}$ et al in which media including TV and radio was the main source of contraceptive information (70\%). ${ }^{15}$ In contrast studies by Pegu B et al the source of information was mainly obtained from health workers $(58.6 \%)$ followed by media $(24.1 \%)$ and social circle $(15.5 \%){ }^{10}$ Also in studies conducted by Omo-Aghoja et al, and Srivastava et al, social circle was found to be the main source of information. ${ }^{7,14}$

\section{CONCLUSION}

In the present study, it was found that majority had knowledge, though not completely, but when it came to utilization of various contraceptive methods, it was suboptimal. The rise in the knowledge about family planning has been mainly due to the media popularizing condoms. Hence, impetus has also to be given to the other methods so that they are better utilized. This shows that there is an urgent need for strong motivation for women to use them. The various reasons for not using contraception was lack of complete knowledge of various methods, social taboos and opposition from husband. This highlights the need for provision of facilities so that all the eligible couples can access valid information regarding all the contraceptive methods.

\section{Funding: No funding sources \\ Conflict of interest: None declared \\ Ethical approval: Not required}

\section{REFERENCES}

1. Khan MM, Shaikh ST, Shroff AG. Study of knowledge and practice of contraception in urban slum community, Mumbai. Int J Curr Med Appl Sci. 2014;3(2):35-41.

2. Vaidyanathan A, Priya KC, Seenivasan P, Malini G, Kaarthika T, Nathan D et al. A comparative study on the contraceptive methods preferred in rural and urban areas in Tamil Nadu. Stanley Med J. 2014;1(2):4-8.

3. Starbird E, Norton M, Marcus R. Investing in family planning: key to achieving the sustainable development goals. Global Health: Sci Prac. 2016;4(2):191-210.

4. Saba H, Kishore K. Assessment of knowledge about contraceptive methods among Bangalore Urban Women. MedPulse-Int Med J. 2014;1(9):508-13.

5. Tilahun T, Coene G, Luchters S, Kassahun W, Leye $\mathrm{E}$, Temmerman $\mathrm{M}$ et al. Family planning knowledge, attitude and practice among married couples in Jimma Zone, Ethiopia. PloS one. 2013;8(4):e61335.

6. Rao PD, Babu MS. Knowledge and use of contraception among Racha Koyas of Andhra Pradesh. Anthropologist. 2005;7:115-9.

7. Omo-Aghoja LO, Omo-Aghoja VW, Aghoja CO, Okonofua FE, Aghedo O,Umueri C. Factors associated with the knowledge, practice and perceptions of contraception in rural southern Nigeria. Ghana Med J. 2009;43:115-21.

8. Becker S. Measuring unmet need: wives, husbands or couples? Int Fam Plann Perspec.1999;25:172-80.

9. Gaikwad S, Sirohi S, Rokade R, Raja RS, Deshmankar B, Banzal B et al. A study on contraceptive knowledge practice (KAP) among women attending family planning clinic of a private hospital of western India. Int $\mathbf{J}$ Recent Trends Sc Tech. 2015;13(3):585-8.

10. Pegu B, Gaur BP, Sharma N, Santa Singh A. Knowledge, attitude and practices of contraception among married women. Int J Reprod Contracept Obstet Gynecol. 2017;3(2):385-8.

11. Young LK, Farquhar CM, McCowan LM, Roberts HE, Taylor J. The contraceptive practice of women seeking termination of pregnancy in an Aukland clinic. NZ Med J. 1994;107:189-91.

12. Sherpa SZ, Sheilini M, Nayak A. Knowledge, attitude, practice and preferences of contraceptive 
methods in Udupi district, Karnataka. J Family Reprod Health. 2013;7(3):115-20.

13. Renjhen P, Gupta SD, Barua A, Jaju S, Khati B. A study of knowledge, attitude and practice of family planning among the women of reproductive age group in Sikkim. $\mathrm{J}$ Obstet Gynecol India. 2008;58:63-7.

14. Srivastava R, Srivastava DK, Jina R, Srivastava K, Sharma N, Sana S. Contraceptive knowledge, attitude and practice (KAP Survey). J Obstet Gynecol India. 2005;55:546-50.
15. Ghike S, Joshi S, Bhalerao A, Kawthalkar A. awareness and contraception practices among women an indian rural experience. J South Asian Federation Obstet Gynecol. 2010;2(1):19-21.

Cite this article as: Nayak AU, Ramakrishnan KG, Venkateswar KN, Vijayshree M. Assessing the knowledge, attitude and practice of contraception in rural India: a necessary step in achieving population control. Int J Reprod Contracept Obstet Gynecol 2017;6:3328-31. 